REVISTA X, Curitiba, volume 13, n.1, p. 255-258, 2018.

Dossiê Especial: Português como Língua Adicional em contextos de minorias:

(co)construindo sentidos a partir das margens

BIZON \& DINIZ (Orgs.)

\title{
EU, EU MESMA E O PORTUGUÊS: EXPERIÊNCIA DOS MEUS (DES)ENCONTROS COM A LÍNGUA PORTUGUESA
}

\section{Me, myself and Portuguese: experience from my (mis)matches with the Portuguese language}

Michelle Andréa MURTA, UFMG ${ }^{1}$

Meu nome é Michelle Andréa Murta, atualmente tenho 36 anos, sou professora de Libras na Universidade Federal de Minas Gerais e o mais importante é que sou surda. Isso mesmo. É muito importante para mim eu ter me assumido como Surda e falante de Libras, que é minha primeira língua. Eu gostaria de narrar um pouco sobre minha trajetória em uma sociedade que me obrigava e me lembrava, a todo momento, que a minha língua tinha que ser o português. Afinal, a própria Constituição Federal de 1988 ignorou completamente a Libras, que foi reconhecida pelo Estado como uma língua da comunidade surda brasileira somente em 2002, com a publicação da lei 10.436 .

Eu, como leiga em questão de meus direitos, moradora do interior de Minas Gerais, na cidade de Salinas, acreditava que somente eu e minha família tínhamos sido "amaldiçoados". É isso mesmo, gente: minha surdez é hereditária. Mas é aí que começa o problema. Eu não nasci surda profunda: tinha um pouco de audição, mas não sabia que grau de audição seria esse. E o pior, eu nem sabia que eu era surda. Dá para acreditar? Nem minhas professoras perceberam que eu tinha uma perda auditiva; muitas acreditavam que eu tinha algum problema cognitivo, pois eu tomava bomba sempre foram cinco ao longo do ensino fundamental. Acreditam que tomei bomba até mesmo na primeira série? Parece piada, né? Mas isso aconteceu.

Demorei para descobrir que o problema não era cognitivo. O problema era a metodologia do ditado. Quem viveu nessa época sabe do que estou falando. A professora avisava: "Agora é o ditado". E eu ficava muito nervosa com esse aviso,

\footnotetext{
${ }^{1}$ Doutoranda em Linguística Teórica e Descritiva pela Universidade Federal de Minas Gerais (UFMG). Email: michelle.murta@gmail.com
} 
REVISTA X, Curitiba, volume 13, n.1, p. 255-258, 2018.

Dossiê Especial: Português como Língua Adicional em contextos de minorias:

(co)construindo sentidos a partir das margens

BIZON \& DINIZ (Orgs.)

porque eu sabia que errava tudo e me sentia burra. A professora falava "mala", eu escrevia "fala"; ditava "lata", eu escrevia "fala", e assim por diante. Eu não tinha domínio de olhar para o papel e ouvir atentamente as palavras. Eu tinha que olhar para ela e tentar fazer leitura labial, o que era comum no meu dia a dia, pois minha mãe e minha avó faziam uso desse método e, para conversar com elas, eu tinha que me articular mais. Poxa vida! Repeti cinco anos devido à bênção do ditado e devido à benção de ninguém. Ninguém mesmo havia percebido que eu era surda, nem mesmo minha família.

Mas chegou o dia em que eu percebi que eu era igual minha mãe. Eu tinha onze anos, já era uma mocinha que queria namorar, sair com as amigas. Foi neste período que descobri que eu ouvia sim, mas não entendia as palavras e, muitas vezes, fingia que entendia. Nem vou contar o que já aconteceu por conta disso... A partir desse momento, descobri por que eu não conseguia falar palavras novas. Custei a aprender a falar "estratégia"; "Uber" sofro até hoje para dizer; e o nome da cidade Teófilo Otoni... ainda bem que não moro lá, porque já desisti de falar o nome dessa cidade.

Gosto de lembrar muita coisa com grande humor, pois o "monstro" português me assombrava todos os dias. Todos os dias era uma pressão diferente para eu aprender a escrever direito, para eu saber que os verbos não são todos no infinitivo, para eu saber que as preposições são necessárias, para eu saber quando usar porque, por que, porquê ou por quê - até hoje tenho dificuldades. As pressões eram tantas a ponto de tornaremse traumas.

Vivenciei uma experiência muito ruim em um local de trabalho. Fui chamada na sala da diretoria com todos os e-mails que eu tinha enviado. Os diretores me questionaram perguntando se eu de fato tinha enviado os e-mails. Ao ler, eu confirmei que sim, que eu tinha escrito; então me ordenaram que eu procurasse o erro. Neste momento, comecei a ficar nervosa. O supervisor me disse assim: "Não tenha pressa. A coisa mais importante agora é você achar seu erro". Eu, como uma pessoa extremamente sensível, comecei a chorar, pois não estava entendendo. Eu lia e relia os e-mails e perguntava para Deus: "Meu Deus, o que tem de errado? Meu Deus, vou perder meu emprego". Não me conformava com a falta de empatia e respeito com a 
REVISTA X, Curitiba, volume 13, n.1, p. 255-258, 2018.

Dossiê Especial: Português como Língua Adicional em contextos de minorias:

(co)construindo sentidos a partir das margens

BIZON \& DINIZ (Orgs.)

minha pessoa. Ora, a empresa me contratou por cota; ela já sabia que eu era Surda. Então o supervisor, já com um ar de deboche, disse o seguinte: "Eu vou circular o seus erros e você me fale qual a palavra certa que devia colocar no lugar, ok?" Eu, no meio de soluços, tomando água para tentar me acalmar, não sabia o que falar. Disse apenas “ok". Ele começou a circular as palavras. Onde estava o erro? Sentada, sem forças para mais nada, vi-o circular, uma a uma, a mesma palavra: "MIM". Ao chegar ao último "mim", ele disse: "Michelle, me responda, por favor. Qual a palavra certa que você tinha que colocar no lugar de 'mim'?" Eu, com toda a minha sinceridade, respondi: “Desculpa minha ignorância, minha formação, mas não sei te responder". Ele, já nervoso, achando que eu estava tirando sarro, pegou a caneta e começou a escrever, com força, em cima. 'O certo é 'EU', 'EU', 'EU', 'EU'. Não é 'mim'. Aprenda isso e nunca mais cometa o mesmo erro". De fato, nunca mais cometi o erro, mas sempre que preciso escrever algo como "Envia para mim o documento", já fico pensando: “Tenho que colocar o 'EU', então o certo seria: 'Envia para eu o documento?' ou 'Envia para me o documento?" "Como gostar de português se tantos "nativos" são ignorantes a ponto de não aceitarem as diversidades linguísticas?

Concluí o ensino médio na luta, sem ter intérprete, tentando decifrar o que os professores estavam falando, pegando pedaços de palavras e já prevendo a frase, contando com apoio dos colegas, e ainda tendo pessoas me parando e perguntando de que país eu sou, pois falava com língua presa e que mal dava para entender. Assim fui me relacionando com o português e com os brasileiros, pois eu era taxada de estrangeiras.

Em 2008, fui aprovada no vestibular de Letras - Libras. Foi nesta graduação que me encontrei e percebi que era aquilo que eu queria. Eu me sentia acolhida, sentia que estava no lugar certo. Era tão bom ver todos se comunicando e eu entendendo tudo claramente. Eu me formei em 2015 e eu tinha um sonho: ser professora em uma universidade federal. Como sou "brasileira", e todo bom brasileiro não desiste, lá fui eu levar tapa na cara. Queria ter diploma de mestrado, para me preparar e me capacitar para ser professora federal. Joguei no Google: "mestrado linguística BH". Apareceu o programa da UFMG. Nem cliquei. O medo era tanto... Apareceu também o programa da 
REVISTA X, Curitiba, volume 13, n.1, p. 255-258, 2018.

Dossiê Especial: Português como Língua Adicional em contextos de minorias:

(co)construindo sentidos a partir das margens

BIZON \& DINIZ (Orgs.)

PUC-Minas. Fiz a inscrição e lá fui eu tentar. Pedi dispensa da prova de inglês, e eles aceitaram, mas me obrigaram a fazer uma prova de português.

Por ter sido classificada em quarto lugar, consegui uma bolsa da CAPES. Apesar disso, tinha um problema muito grande para cursar este mestrado: o nome era "Linguística e língua portuguesa". Aí pronto. Começou mais uma "guerra". Os professores afirmavam que eu devia ter fluência no português, pois eu receberia o diploma de mestre em língua portuguesa, e eu insistia: "Eu não quero língua portuguesa, não vou dar aula de língua portuguesa. Quero apenas me especializar em linguística, e meu foco é a língua de sinais". Foi uma situação muito chata, me senti muito magoada. Por não ter tanta fluência no português, não atendi às exigências e perdi a bolsa da Capes no segundo ano. Acreditem: eu pago por ela até hoje. Tenho certeza de que, se eu fosse fera no português, não teria perdido, mas enfim... Foi mais um desencontro com o português, mais um assombramento, mais uma luta.

Essa luta ainda não acabou. Sei que hoje, e para todo o resto da minha vida, eu verei o português em todos os lugares. Inclusive estou com ele aqui, narrando minha experiência, mas hoje ele não é aquele monstro mais. Já é mais mansinho. 